\title{
Mechanical Properties of Carbon Fiber Reinforced Concrete
}

\author{
Sahar Y. Ghanem', Ph.D.; Jonathan Bowling² \\ ${ }^{1}$ Assistant Professor, corresponding author (s.ghanem@moreheadstate.edu)
}

Department of Engineering \& Technology Management, Morehead State University, 210 Lloyd Cassity Building, Morehead, KY ,40351, USA.

${ }^{2}$ Undergraduate Student, Department of Engineering \& Technology Management, Morehead State University, 210 Lloyd Cassity Building, Morehead, KY ,40351, USA.

\begin{abstract}
Fibers are used to improve the properties of concrete. This paper investigates the mechanical properties of chopped carbon fiber-reinforced concrete (CFRC). The properties examined include workability, compressive strength, splitting tensile strength, and flexural strength. The fibers were added at the volume fractions of $0.5,1.0,1.5$, and 2.0 percent. Adding carbon fiber to the concrete decreased the workability of concrete. Compressive strength of CFRC increases with increasing fiber content up to a certain percentage, after which increasing fiber content becomes unbeneficial. This optimum fiber content is found to be 1 percent, with strength effectiveness of 13.65 percent. The splitting tensile strength of CFRC improved linearly with increased fiber content, and the strength effectiveness ranged from 18.37 percent to 132.6 percent. The flexural strength of CFRC improved linearly with increasing fiber content, and the strength effectiveness ranged from 3.26 percent to 13.82 percent. Relationships for compressive strength, splitting tensile strength, and flexural strength of CFRC are introduced.
\end{abstract}


Keywords: Fiber-reinforced concrete; carbon fibers; workability; compressive strength, splitting tensile strength; flexural strength.

\section{Introduction}

Fiber-reinforced concrete (FRC) is a material made of cements, water, and fine and coarse aggregate, with added discontinuous fibers. [1]. Fibers are used to improve the properties of concrete, and various types of fibers are used for this purpose: steel fiber, glass fiber, natural fiber and synthetic fiber [2]. Although research on carbon fiber reinforced concrete CFRC started as early as the 1970s nineteen seventies [3], most studies in literature focused on the effect of steel fibers $[4,5,6]$.

The first study of carbon fibers in cement-based matrices was in the form of continuous high-modulus polyacrylonitrile (PAN) fibers by Ali et al. in 1972 [3], where they reported a significant improvement in the mechanical properties. However, this type of carbon fibers did not prevail due to its high cost. In the early 1980 s, as pitch-based CF, was developed in Japan. It is inexpensive low modulus $\mathrm{CF}$ made from coal and petroleum pitches, and a significant improvement in the mechanical properties of cement-based materials were reported as well $[7$, 8]. The effect of carbon fiber addition on the properties of concrete increases with fiber volume fraction, even with fiber volume fraction as low as $0.2 \%$ [9].

Concrete mixed with carbon fibers shows very low rates of cracking and is effective in controlling plastic shrinkage cracks [10]. This reinforcement is superior compared to steel, polypropylene or glass fibers in its finishability, thermal resistance, weatherability, ability to mix high fiber contents, and chemical stability in aggressive environments [11]. 
Short carbon fiber cement-matrix composites exhibit attractive flexural properties [12]. Researchers reported an increase in the first crack and flexural strengths of the specimens with the increase in CF percentage $[7,13,14]$. Several researches concluded that CFRC has a good tensile behavior [7, 8, 15, 12]. Kim and Park [14] concluded that the tensile strength increases with increasing the volume fiber content.

Few studies $[16,17]$ reported that the compressive strength of cement pastes reinforced with carbon fibers is superior than that of the base matrix, Other studies reported that the compressive strength of the mortars is almost unaltered by carbon fiber inclusion $[18,19]$. While Giner et al. [20] showed that adding carbon fiber lead to slight decreases of the compressive strength compared to the reference concrete. Due to the good tensile and flexural properties of CFRC, this advanced material is very beneficial in building special structures, such as roofing sheets, panels, tiles and curtain walls [11].

The majority of studies investigating carbon fiber in civil engineering applications are performed on Cementous composites or mortar [21, 22, 23, 24, 15] not concrete. Moreover, research on carbon fiber reinforced concrete in literature use a limited fiber content $[25,26,27$, 17], mainly not more than $1 \%$ with few exceptions [28].

The main objective of this paper is to study the mechanical properties of Carbon Fiber Reinforced Concrete (CFRC) with a wide range of four fiber contents and up to $2 \%$. An experimental study is carried out to investigate concrete reinforced with carbon fiber under several tests: workability, compressive strength, splitting tensile strength test, and flexural strength test. Investigated fiber content dosage $\left(V_{f} \%\right)$ are: $0.5,1.0,1.5$, and 2.0 percent by volume of concrete. 


\section{Experimental Investigation}

\section{MATERIALS}

Concrete has been produced using certain proportions of carbon fibers, fine aggregate, coarse aggregate, cement, and water.

The mix proportion 1: 1.4: 2 (cement: fine aggregate: coarse aggregate) by weight is kept constant on all mixes, but the carbon fiber content varies in mixes. General purpose Portland cement with specific gravity 3.15 is used ASTM C150 [29]. Normal density coarse aggregate with a maximum size of $12.5 \mathrm{~mm}$ are used. The specific gravity and Absorption are calculated in accordance to ASTM C 127 [30] and equal to 2.7 and $1.12 \%$ respectively. Fine aggregate used has. The specific gravity and Absorption are calculated in accordance to ASTM C 128 [31] and equal to 2.68 and $1.15 \%$ respectively, and the fineness modulus is calculated to be 2.3 using ASTM C136 [32].

Fiber used to reinforce concrete is carbon chopped fiber shown in Fig.1.

Table 1 presents the fiber's mechanical properties; these data were obtained from the manufacturer website [33].

\section{MIXTURES}

Five mixtures are designed with varied fiber contents: M0, M0.5, M1, M1.5, and M2. The mixtures' names have two parts: the letter M refers to the word "Mixture," followed by a number that represent the fiber content ratio in the mixture. Therefore, M0, M0.5, M1, M1.5, and M2 are mixtures with no fiber, $0.5,1,1.5$ and 2 percent fiber content respectively. 
Materials are mixed using a mixer. The coarse and fine aggregates are mixed for 1 minute, then cement is added and mixed for another 1 minute. Water is added next and mixed with dry materials. For mixtures with fibers, fibers are added at the end of the process, after all other materials are mixed [1].

It was noticed that, due to fiber small density, the fibers will stick to the mixer's walls. To avoid that, fibers are added gradually and the mixtures are mixed for additional 3 minutes to dispense fibers evenly. During this process, the mixer is stopped during mixing after each minute to manually ensure that all fibers are mixed.

After mixing concrete, it is molded in cylinders and beams molds. Cylinders are $150 \mathrm{~mm}$ (6 in.) diameter and $300 \mathrm{~mm}$ length ( $12 \mathrm{in}$.), and beams are 150 by 150 by $500 \mathrm{~mm}$ [ 6 by 6 by 20 in.]. They were left in the molds for 24 hours at room temperature, and then removed and cured in water for 28 days before testing.

\section{TESTS SETUP}

Four tests are performed to investigate the behavior of CFRC: workability, compressive strength, splitting tensile strength test, and flexural strength test.

Workability is tested directly after mixing each patch using slump test according to ASTM C143 [34]. Compressive strength is tested according to ASTM C39 [35]. Concrete specimens tested are cylinders with $150 \mathrm{~mm}$ (6 in.) diameter and $300 \mathrm{~mm}$ length (12 in.).

The splitting tensile strength test is performed based on ASTM C496 [36]. Concrete specimens tested are cylinders with $150 \mathrm{~mm}$ (6 in.) diameter and $300 \mathrm{~mm}$ length (12 in.). 
The flexural strength test is performed based on ASTM C1609 [37], concrete specimens tested are 150 by 150 by $500 \mathrm{~mm}$ [ 6 by 6 by 20 in.] tested on a $450 \mathrm{~mm}$ [ $18 \mathrm{in}$.] span beams.

\section{Test Results and Discussion}

A total of 18 specimens were tested in this paper. Six plain concrete (M0) specimens are casted: two cylinders for compressive strength test, two cylinders for tensile strength test, and two beams for flexural strength test. The recorded results for plain concrete are the average of the two specimens for each test. For the reinforced mixtures One'specimen is casted for each test. Figure 2 shows the specimens at 28 days.

\section{WORKABILITY}

Concrete workability is that property of freshly mixed concrete that affects the ease with which it can be mixed, placed, consolidated, and struck off [38].

The results of slump test are listed in Table 2. The slump of concrete decreases with increasing the fiber content in the mixture. Looking at Fig. 3, the relationship between slump and fiber content is linear. An increase of the fiber content up to 2 percent results in the slump decreasing by 85 percent of the unreinforced specimen M0.

Several studies found the porosity and the air content increases with increasing the carbon fiber content $[9,23]$. Additionally, in an experiment performed on steel fiber reinforced concrete, it was found that mixtures with lower slump tends to have higher air contents [39]. Furthermore, the greater the paste content, i.e. the volume fraction of the fluid phase within which the fibers can move and rotate, the greater the workability for fibers [40]. It was noticed during mixing that with an increase in the fiber content mixing and rodding concrete was more challenging. 
The relationship can be expressed in the following equation:

slump $=$ slump $p_{0}-33.4 V_{f}$

Where $s l u m p_{0}$ is the slump of concrete mix without fiber (M0 in this study).

Therefore, it can be concluded that workability and fiber dispensability of fresh carbon fiber reinforced concrete are strongly dependent on fiber content.

\section{COMPRESSIVE STRENGTH}

Concrete compressive strength at 28 days $f_{c}$. value for all mixtures are listed in Table 3. Based on Table 3, the compressive strength of concrete for M0.5 and M1 and M1.5 is higher than compressive strength of specimen $\mathrm{M} 0$. On the other hand, as the fiber content got higher in M2, concrete compressive strength becomes less than M0.

Based on Fig. 4, the rate of increase in concrete compressive strength decreases as the fiber content becomes more than 1 percent, similar finding was concluded in Chung 1992 [17] for mortar. That implies that after certain fiber content, any addition of fiber will not give any further improvement in concrete compressive strength. For current study and material, this fiber content is 1 percent, at which the strength effectiveness is 13.65 percent, where strength effectiveness is

StrengthEffectiveness $=\frac{\text { strength }_{F R C}-\text { strength }_{M_{0}}}{\text { strength }_{F R C}} \leftrightarrow 00 \%$

Where strength FRC and strength $M \rho$ are strength of fiber reinforced concrete and unreinforced concrete $\left(M_{0}\right)$ strength respectively.

The curve is exactly a fourth-degree equation with correlation coefficient $R^{2}=0.99$, and can be expressed in the following equation: 
$f_{c}^{\prime}=16.84 V_{f}^{4}-68.12 V_{f}^{3}+80.17 V_{f}^{2}-23.3 V_{f}+\left(f_{c}^{\prime}\right)_{0}$

Where $\left(f_{c}^{\prime}\right)_{0}$ is the compressive strength of concrete mixture without fiber (M0 in this study).

The initial addition of fibers provides a reinforcement, but at higher fiber content concentrations, the homogeneity of concrete; which is strong under compression; disrupted by fiber which cause a decrease in the compressive strength of concrete [41].

As mentioned before, the air content increases as the fiber content increases. There are two changing factors to consider inhere: air content and fiber content. At fiber contents less than $1 \%$, the increase in compressive strength due to fibers overweigh the decrease in the compressive strength due to the increase in air content until it reaches a maximum certain fiber content which afterward, the decrease in the compressive strength due to the increase in air content overweigh the increase in compressive strength due to fibers. Further investigation is needed to determine the factors that influence the optimum fiber content and fitting model for compressive strength.

\section{SPLITTING TENSILE STRENGTH}

Splitting tensile strength $(T)$ results for all mixtures are listed in Table 4. Based on Table 4, the splitting tensile strength of concrete increases linearly by increasing the fiber content in the mixture. This linear relationship is shown in Fig. 5, and can be expressed in the following relationship:

$$
T=0.84 V_{f}+T_{0}
$$

Where $T_{0}$ is the splitting tensile strength of concrete mixture without fiber (M0 in this study). 
With $0.5,1,1.5$ and 2 percent fiber content, the splitting tensile strength increased by $18.37,42.86,74.15$ and 132.6 percent respectively. It can be noticed that the increase in the splitting tensile strength is significant when 2 percent fiber content is used.

For carbon fiber composites under tension, stress is transferred to the fiber through shear stresses at the interface until the fiber reaches its tensile strength and fractures. The segmented fiber continues to carry load and fracture into shorter segments until shear load transfer is no longer sufficient [42].

\section{FLEXURAL STRENGTH}

Flexural strength $(f)$ results for all mixtures are listed in Table 5. Based on Table 5, the flexural strength of concrete increases when the fiber content in the mixture is increased.

Fig. 6 shows that the relationship between flexural strength $(f)$ and fiber content is close to linear, and can be expressed in the following equation:

$f=0.46 V_{f}+f_{0}$

Where $f_{0}$ is the flexural strength of concrete beam without fiber (M0 in this study).

With $0.5,1,1.5$, and $2 \%$ percent fiber content, the flexural strength increased by $3.26,5$, 13.17 , and 13.82 percent respectively. The increase in the flexural strength is significant when 1.5 percent fiber content or more is used.

At low fiber content, the failure mode is not clear, but with increasing the fiber content, the fiber at the failed section was pulled out (Fig. 7.). Composites with strong interface bond 
have a high strength and stiffness which attributes to a difficulty to pull out fiber from the matrix at cracks locations [43]. Fibers will act as a reinforcement and bridge microcracks and prevents the expansion. Also, given that pulling the fibers out absorbs more energy [44], the flexural strength will increase with increasing the fiber content.

\section{Conclusions}

The study presents an experimental investigation of concrete reinforced with carbon fiber performing several tests: workability, compressive strength, splitting tensile strength test, and flexural strength test. Investigated fiber content dosages $\left(V_{f} \%\right)$ are $0.5,1.0,1.5$, and 2.0 percent by volume of concrete.

Based on the test results of this study for the properties of Carbon Fiber Reinforced Concrete (CFRC), the following conclusions can be drawn:

- Adding carbon fiber to the concrete decreases the workability of concrete, introduces difficulties to reach full compaction, and increases the mixing time.

- Compressive strength of FRC increases with an increase of fiber content up to a certain percentage, after which increasing fiber content becomes unbeneficial. For this study, this optimum fiber content is found to be 1 percent with strength effectiveness 13.65 percent. the relationship between compressive strength and fiber content is a fourth-degree equation.

- The splitting tensile strength of FRC improved with increasing fiber content. The relationship between the splitting tensile strength and fiber content is linear, and the strength effectiveness ranged from 18.37 to 132.6 percent. 
- The flexural strength of FRC improved with increasing fiber content. The relationship between the flexural strength and fiber content is linear, and the strength effectiveness ranged from 3.26 to 13.82 percent.

- Relationships for compressive strength, splitting tensile strength, and flexural strength of FRC are introduced.

\section{ACKNOWLEDGMENTS}

Support for the project was made available by the Research and Creative Productions

Committee, Morehead State University.

The authors are also grateful to Zoltek for supplying the carbon fibers.

\section{References}

[1] ACI Committee 544, "Guide for Specifying, Proportioning, and Production of Fiber-Reinforced Concrete," American Concrete Institute, Farmington Hills, MI, 2008.

[2] S. Yin, R. Tuladhar, F. Shi, M. Combe, T. Collister and N. Sivakugan, "Use of macro plastic fibres in concrete: A review," Construction and Building Materials, vol. 93, p. 180-188. DOI: 10.1016/j.conbuildmat.2015.05.105, 2015.

[3] M. A. Ali, A. Majumdar and D. Rayment, "Carbon Fiber Reinforcement of Cement," Cement and Concrete Research, vol. 2, no. 2, pp. 143-161, 1972.

[4] G. R. Williamson, "THE EFFECT OF STEEL FIBERS ON THE COMPRESSIVE STRENGTH OF CONCRETE," ACI Special Publication, vol. 44, pp. 195-208, 1974.

[5] F. Wafa and S. Ashour, "Mechanical properties of high-strength fiber reinforced concrete," $A C I$ Materials Journal, vol. 89, no. 5, pp. 449-455, 1992.

[6] J. Barros and J. Figueiras , "Flexural behavior of steel fiber reinforced concrete: testing and modelling," ASCE Journal of Materials in Civil Engineering, vol. 11, no. 4, p. 331-339, 1999. 
[7] Y. A. M. a. E. M. Ohama, "Properties of Carbon Fiber Reinforced Cement with Silica Fume," $A C I$ Concrete International, vol. 7, no. 3, pp. 58-62, 1985.

[8] S. Akihama, T. Suenaga and H. Nakagawa, "Carbon fiber reinforced concrete," Concrete International, vol. 10, no. 1, pp. 40-47, 1988.

[9] P. Chen and . D. D. L. Chung., "Concrete reinforced with up to 0.2 volume-percent of short," Composites, vol. 24, no. 1, pp. 33-52, 1993.

[10] A. Naaman, T. Wongtanakitcharoen and G. Hauser, "Influence of Different Fibers on Plastic Shrinkage Cracking of Concrete," ACI Materials Journal, vol. 102, no. 1, pp. 49-58, 2005.

[11] N. Banthia, "Carbon Fiber Reinforced Cements: Structure, Performance, Applications and Research Needs," ACI Special Publication, vol. 142, pp. 91-120, 1994.

[12] D. Chung, "Carbon Fiber Cement-Matrix Composites," TANSO, vol. 190, pp. 300-312, 1999.

[13] N. Banthia and J. Sheng, "Micro-reinforced cementitious materials," Boston, MA, 1990.

[14] . T. J. Kim and C. K. Park, "Flexural and tensile strength developments of various shape carbon fiber-reinforced lightweight cementitious composites," Cement and Concrete Research, vol. 28, no. 7, pp. 955-960, 1998.

[15] D. Chung, "Cement reinforced with short carbon fibers: a multifunctional material," Composites Part B: Engineering, vol. 31, pp. 511-526, 2000.

[16] S. Furukawa, Y. Tsuji and M. Miyamoto, "In Review of the 41st General Meetingffechnical Session (CAJ Review 1987)," Cement Association of Japan, pp. 336-339, 1987.

[17] D. Chung, "Carbon Fiber Reinforced Concrete," Strategic Highway Research Program, Washington, DC., 1992.

[18] Y. Ohama and M. Amano, "Effects of Silica Fume and Water Reducing Agent on Carbon Fiber Reinforced Mortar," in Proceedings- Japan Society of Materials Science, Kyoto, Japan, 1984.

[19] J. Sheng, Fracture of Micro-reinforced Cements, Quebec, Canada: Laval University, Ph.D. Thesis, 1996.

[20] V. Giner, . F. Baeza, S. Ivorra, E. Zornoza and Ó. Galao, "Effect of steel and carbon fiber additions on the dynamic properties of concrete containing silica fume," Materials and Design, vol. 34, p. $332-339,2012$.

[21] H. Sakai, K. Takahashi, Y. Mitsui, T. Ando, M. Awata and T. Hoshijima, "Flexural Behavior of Carbon Fiber Reinforced Cement Composite," ACI Special Publication, vol. 142, pp. 121-140, 1994.

[22] S. Park, M. Seo, H. Shima and K. Rheeb, "Effect of different cross-section types on mechanical properties of carbon fibers-reinforced cement composites," Materials Science and Engineering , vol. 366, no. 2, p. 348-355, 2004. 
[23] P. Garcés, J. Fraile, E. Vilaplana-Ortego, D. Cazorla-Amorós, E. Alcocel and L. Andión, "Effect of carbon fibres on the mechanical properties and corrosion levels of reinforced portland cement mortars," Cement and Concrete Research, vol. 35, no. 2, pp. 324-331, 2005.

[24] F. Baeza, O. Galao, E. Zornoza and P. Garcés, "Effect of aspect ratio on strain sensing capacity of carbon fiber reinforced cement composites," Materials and Design, vol. 51, pp. 1085-1094, 2013.

[25] S. Ivorra , P. Garcés, G. Catalá, L. Andión and E. Zornoza, "Effect of silica fume particle size on mechanical properties of short carbon fiber reinforced concrete," Materials and Design, vol. 31, p. 1553-1558, 2010.

[26] V. Giner, F. Baeza, S. Ivorra, E. Zornoza and Ó. Galao, "Effect of steel and carbon fiber additions on the dynamic properties of concrete containing silica fume," Materials and Design, vol. 34, p. $332-339,2012$.

[27] Z. Tabatabaei , J. Volz , D. Keener and B. Gliha, "Comparative impact behavior of four long carbon fiber reinforced concretes," Materials and Design, vol. 55, pp. 212-223, 2014.

[28] G. Campione, S. Mindess and G. Zin, "Compressive Stress-Strain Behavior of Normal and HighStrength Carbon-Fiber Concrete Reinforced with Steel Spirals," ACI Materials Journal, vol. 96, no. 1, pp. 27-34, 1999.

[29] ASTM, "ASTM C150: Standard Specification for Portland Cement," ASTM, West Conshohocken, PA, 2018.

[30] ASTM, "ASTM C127: Standard Test Method for Relative Density (Specific Gravity) and Absorption of Coarse Aggregate," ASTM, West Conshohocken, PA, 2015.

[31] ASTM, "ASTM C 128: Standard Test Method for Relative Density (Specific Gravity) and Absorption of Fine Aggregate," ASTM, West Conshohocken, PA, 2015.

[32] ASTM, "ASTM C136: Standard Test Method for Sieve Analysis of Fine and Coarse Aggregates," ASTM, West Conshohocken, PA, 2014.

[33] Zoltek, "Technical Datasheet. ZOLTEK PX35 Chopped Fiber (Type -55)," Zoltek, [Online]. Available: http://zoltek.com.

[34] ASTM, "ASTM C143: Standard Test Method for Slump of Hydraulic-Cement Concrete," ASTM, West Conshohocken, PA, 2015.

[35] ASTM, "ASTM C39: Standard Test Method for Compressive Strength of Cylindrical Concrete Specimens," West Conshohocken, PA, 2018.

[36] ASTM, "ASTM C496: Standard Test Method for Splitting Tensile Strength of Cylindrical Concrete Specimens," ASTM, West Conshohocken, PA, 2017.

[37] ASTM, "ASTM C1609: Standard Test Method for Flexural Performance of Fiber-Reinforced Concrete (Using Beam With Third-Point Loading)," ASTM, West Conshohocken, PA, 2011. 
[38] ASTM Subcommittee: C09.91, "C125. Standard Terminology Relating to Concrete and Concrete Aggregates," ASTM, West Conshohocken, PA, 2016.

[39] M. Bayasi and P. Soroushian, "Effect of Steel Fiber Reinforcement on Fresh Mix Properties of Concrete," ACI Materials Journal., vol. 89, no. 4, pp. 369-374, 1992.

[40] G. Peiffer and P. Soukatchoff, "Special Concretes - Workability and Mixing," in RILEM Proceedings 24, E \& FN Spon, 1994.

[41] O. Gencel, W. Brostow , T. Datashvili and M. Thedford, "Workability and Mechanical Performance of Steel Fiber-Reinforced Self-Compacting Concrete with Fly Ash," Composite Interfaces, vol. 18, no. 2, pp. 169-184, 2011.

[42] Y. Lin, G. Ehlert and H. Sodano, "Increased Interface Strength in Carbon Fiber Composites through a ZnO Nanowire Interphase," Advanced Functional Materials, vol. 19, no. 16, pp. 2654$2660,2009$.

[43] R. Wang, S. Zheng and Y. Zheng, Polymer Matrix Composites and Technology, Beijing,China: Woodhead Publishing, 2011.

[44] N. Wang , S. Mindess and . K. Ko, "Fibre reinforced concrete beams under impact loading," Cement and Concrete Research, vol. 26, no. 3, pp. 363-376, 1996.

\section{List of Tables}

Table 1. Mechanical properties of chopped carbon fiber [33]

Table 2. Slump test results

Table 3. Compressive strength test results

Table 4. Splitting tensile strength test results

Table 5. Flexural strength test results 


\section{List of Figures:}

Fig. 1. Chopped carbon fiber

Fig. 2. Specimens at 28 days (a) M0 (b) M0.5 (c) M1 (d) M1.5 (e) M2

Fig. 3. Relationship between slump and fiber content

Fig. 4. Relationship between compressive strength and fiber content

Fig. 5. Relationship between splitting tensile strength and fiber content

Fig. 6. Relationship between flexural strength and fiber content

Fig. 7. Failure of beam of mix M1.5 under flexural load 
Table 1. Mechanical properties of chopped carbon fiber [33]

Property

Typical value

Tensile Strength (GPa)

0.1

Elongation 0.024

Tensile Modulus (GPa)

Flexural Strength (GPa) 5

Flexural Modulus (GPa) 134

Fiber Length $(\mathrm{mm})$ 16

$1 \mathrm{GPa}=145 \mathrm{ksi} ; 1 \mathrm{~mm}=0.039$ in. 
Table 2. Slump test results

\begin{tabular}{lr}
\hline Mixture & $\mathrm{mm}$ \\
\hline M0 & 85 \\
\hline M0.5 & 61 \\
\hline M1 & 48 \\
\hline M1.5 & 38 \\
\hline M2 & 13 \\
\hline & $1 \mathrm{~mm}=0.039$ in.
\end{tabular}

Table 3. Compressive strength test results

\begin{tabular}{cccc}
\hline Mixture & Load at failure & $\begin{array}{c}\text { Compressive } \\
\text { strength () }\end{array}$ & $\begin{array}{c}\text { Strength } \\
\text { effectiveness }\end{array}$ \\
\hline M0 & $(\mathrm{kN})$ & $(\mathrm{MPa})$ & $(\%)$ \\
\hline M0.5 & 721.99 & 40.88 & - \\
\hline M1 & 738.30 & 41.80 & 2.26 \\
\hline M1.5 & 820.57 & 46.46 & 13.65 \\
\hline M2 & 735.84 & 41.66 & 1.92 \\
\hline & 697.40 & 39.48 & -3.41 \\
\hline & $1 \mathrm{kN}=224.8 \mathrm{lbs} ; \mathrm{MPa}=0.145 \mathrm{ksi}$ &
\end{tabular}


Table 4. Splitting tensile strength test results

\begin{tabular}{cccc}
\hline Mixture & Load at failure & $\begin{array}{c}\text { Splitting tensile } \\
\text { strength (T) }\end{array}$ & $\begin{array}{c}\text { Strength } \\
\text { effectiveness }\end{array}$ \\
\hline M0 & $(\mathrm{kN})$ & $(\mathrm{MPa})$ & $(\%)$ \\
\hline M0.5 & 104 & 1.47 & 18.37 \\
\hline M1 & 123 & 1.74 & 42.86 \\
\hline M1.5 & 148.1 & 2.10 & 74.15 \\
\hline M2 & 180.81 & 2.56 & 132.6 \\
\hline
\end{tabular}


Table 5. Flexural strength test results

\begin{tabular}{cccc}
\hline Mixture & Peak load & Flexural strength $(\boldsymbol{f})$ & $\begin{array}{c}\text { Strength } \\
\text { effectiveness }\end{array}$ \\
\hline M0 & $(\mathrm{kN})$ & $(\mathrm{MPa})$ & $(\%)$ \\
\hline M0.5 & 41.63 & 5.55 & 3.26 \\
\hline M1 & 42.99 & 5.73 & 5.00 \\
\hline M1.5 & 43.71 & 5.83 & 13.17 \\
\hline M2 & 47.11 & 6.28 & 13.82 \\
\hline & 48.30 & 6.44 &
\end{tabular}

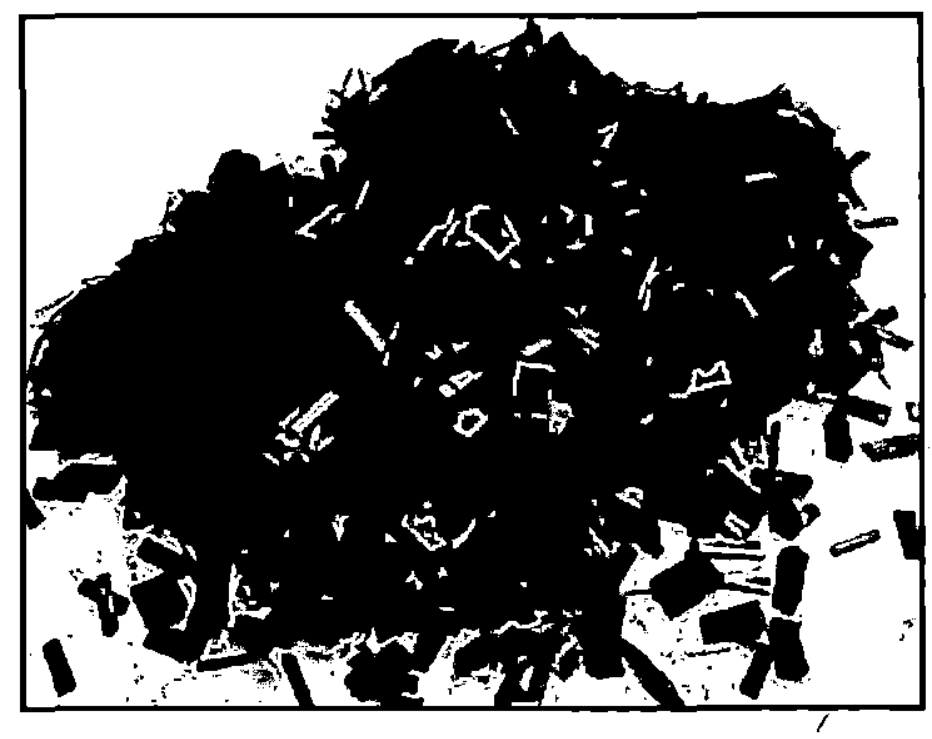

Fig. 1. Chopped carbon fiber 


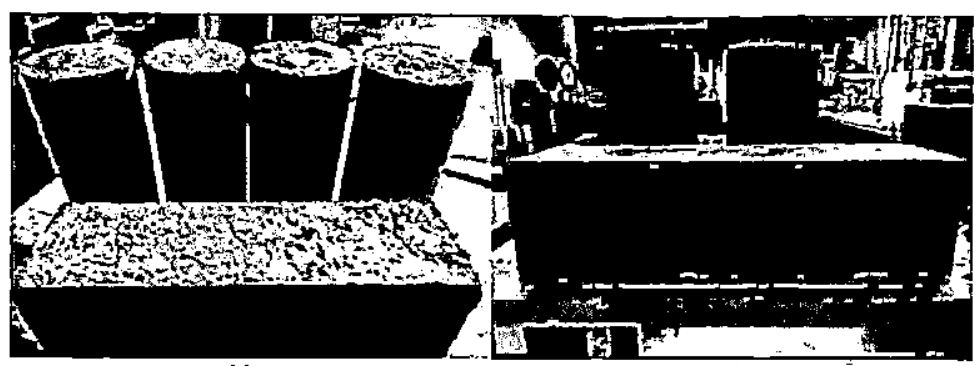

(a)

(b)

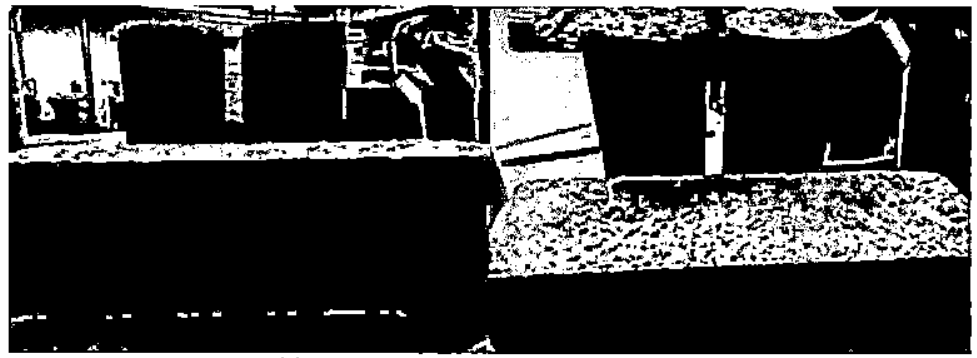

(c)

(d)

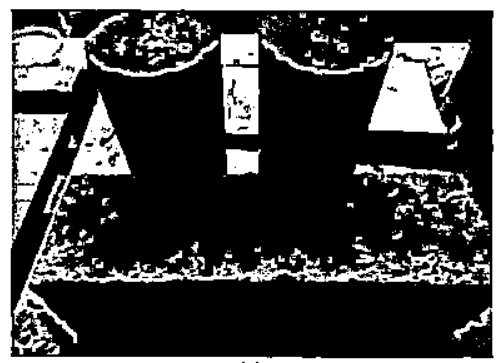

(e)

Fig. 2. Specimens at 28 days (a) M0 (b) M0.5 (c) M1 (d) M1.5 (e) M2 


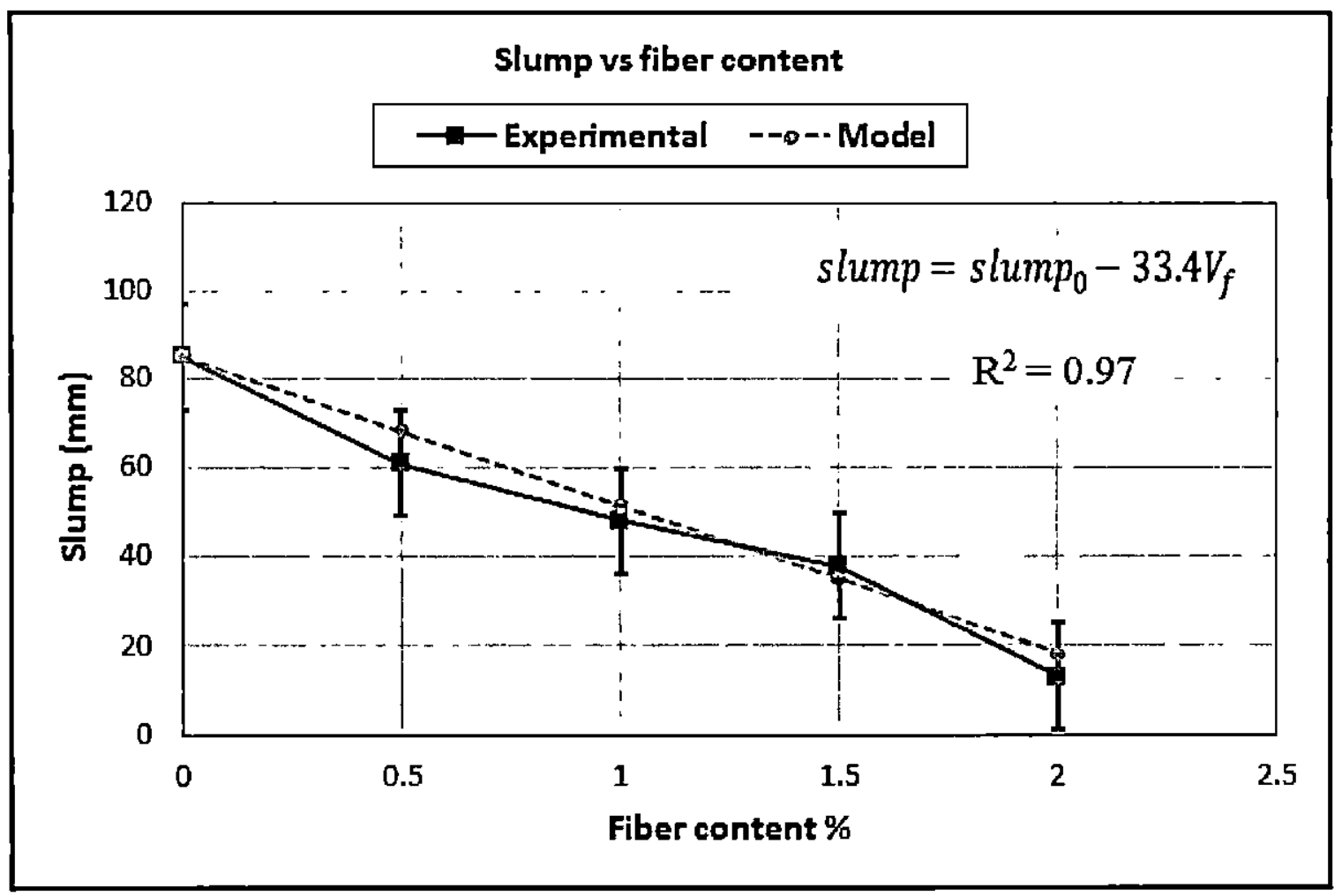

Fig. 3. Relationship between slump and fiber content

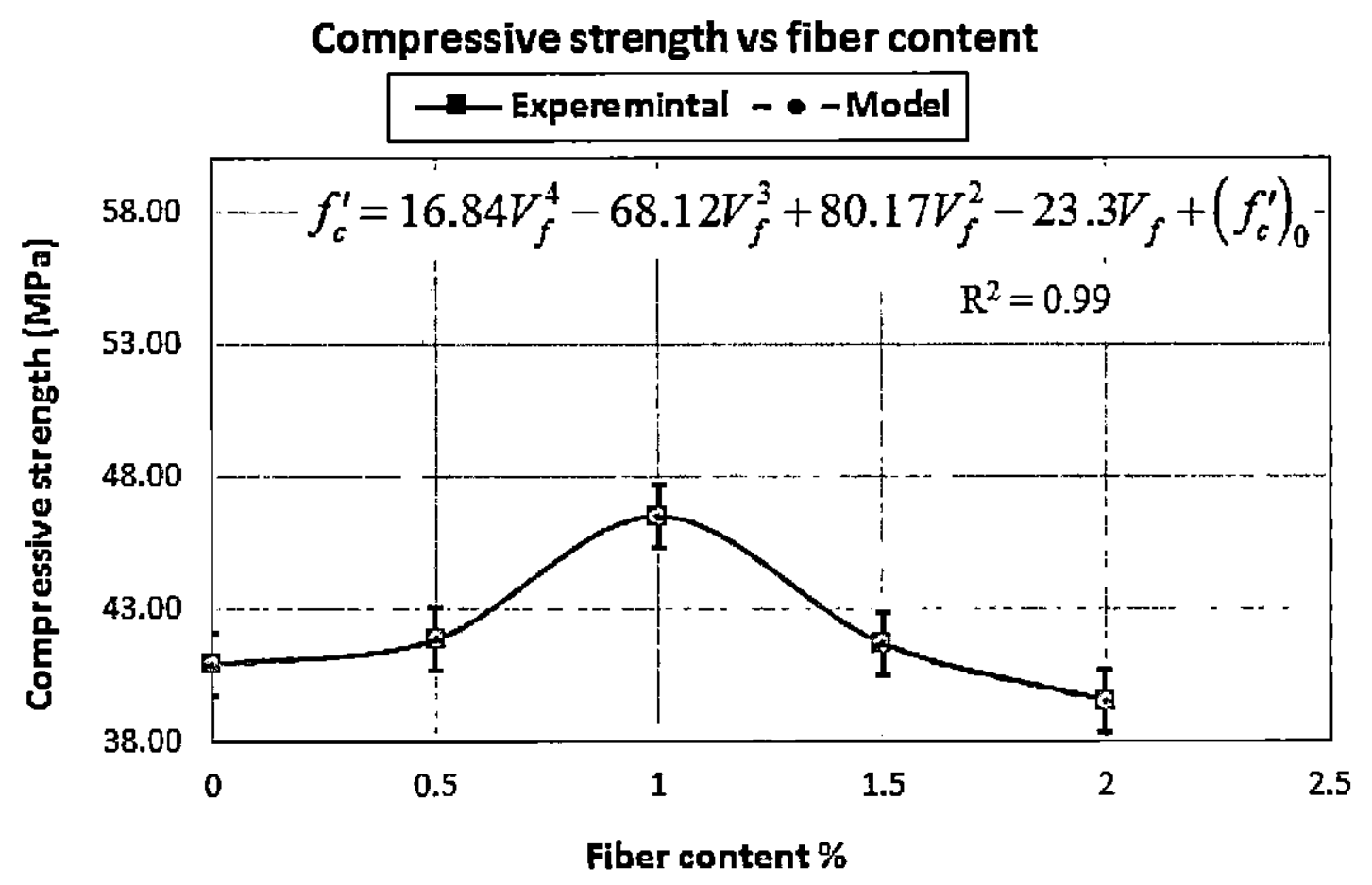

Fig. 4. Relationship between compressive strength and fiber content 


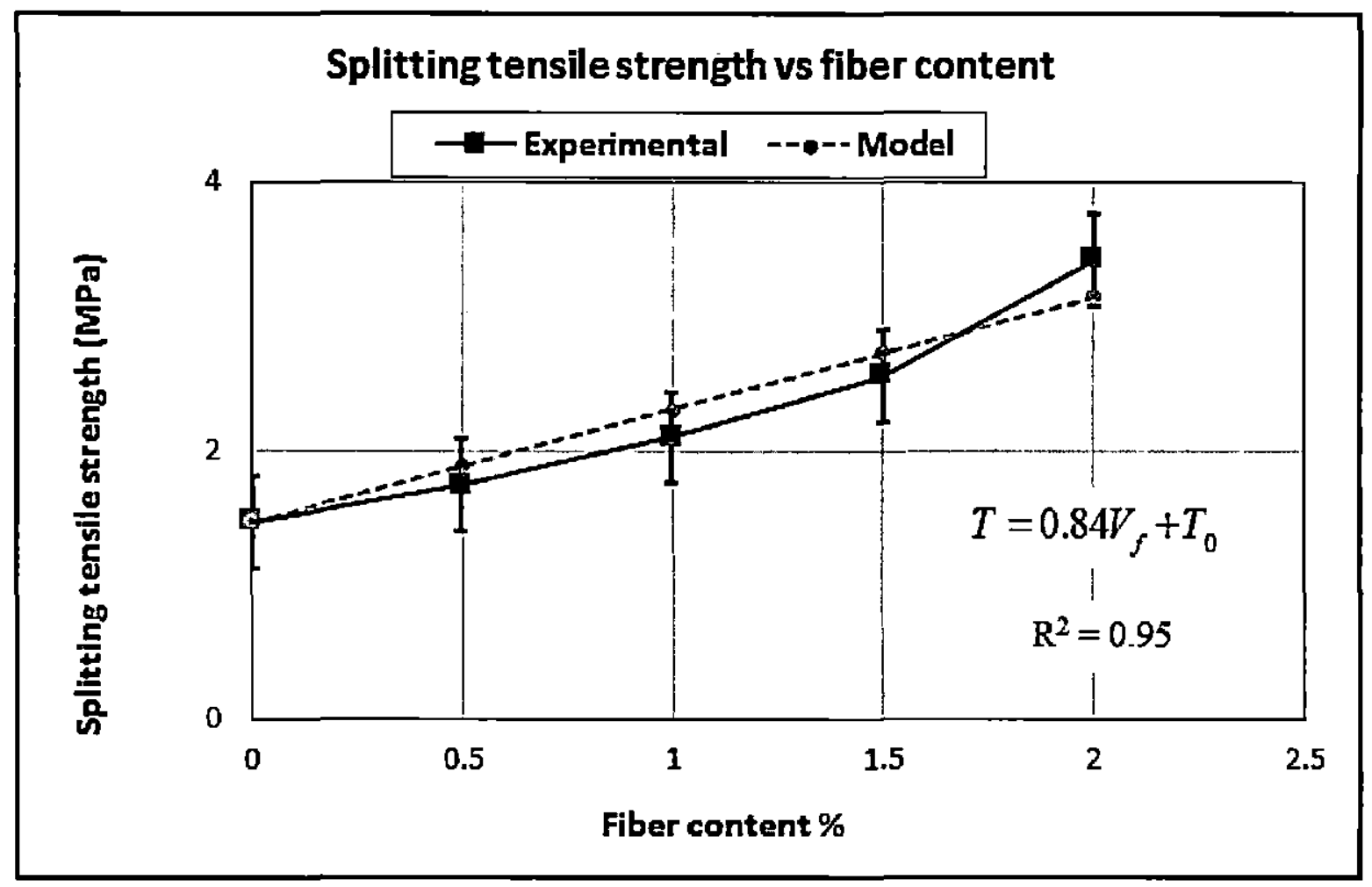

Fig. 5. Relationship between splitting tensile strength and fiber content 


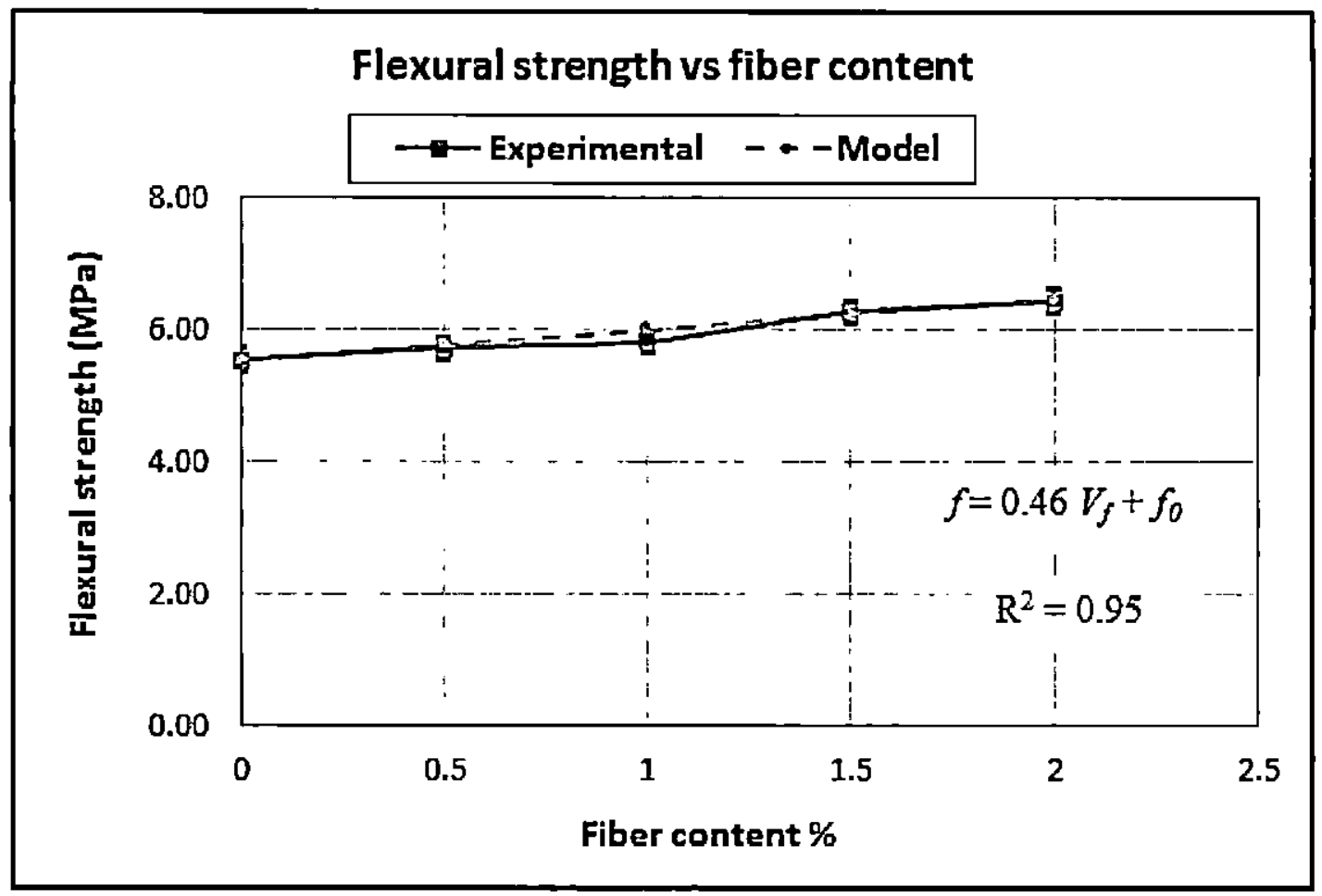

Fig. 6. Relationship between flexural strength and fiber content 

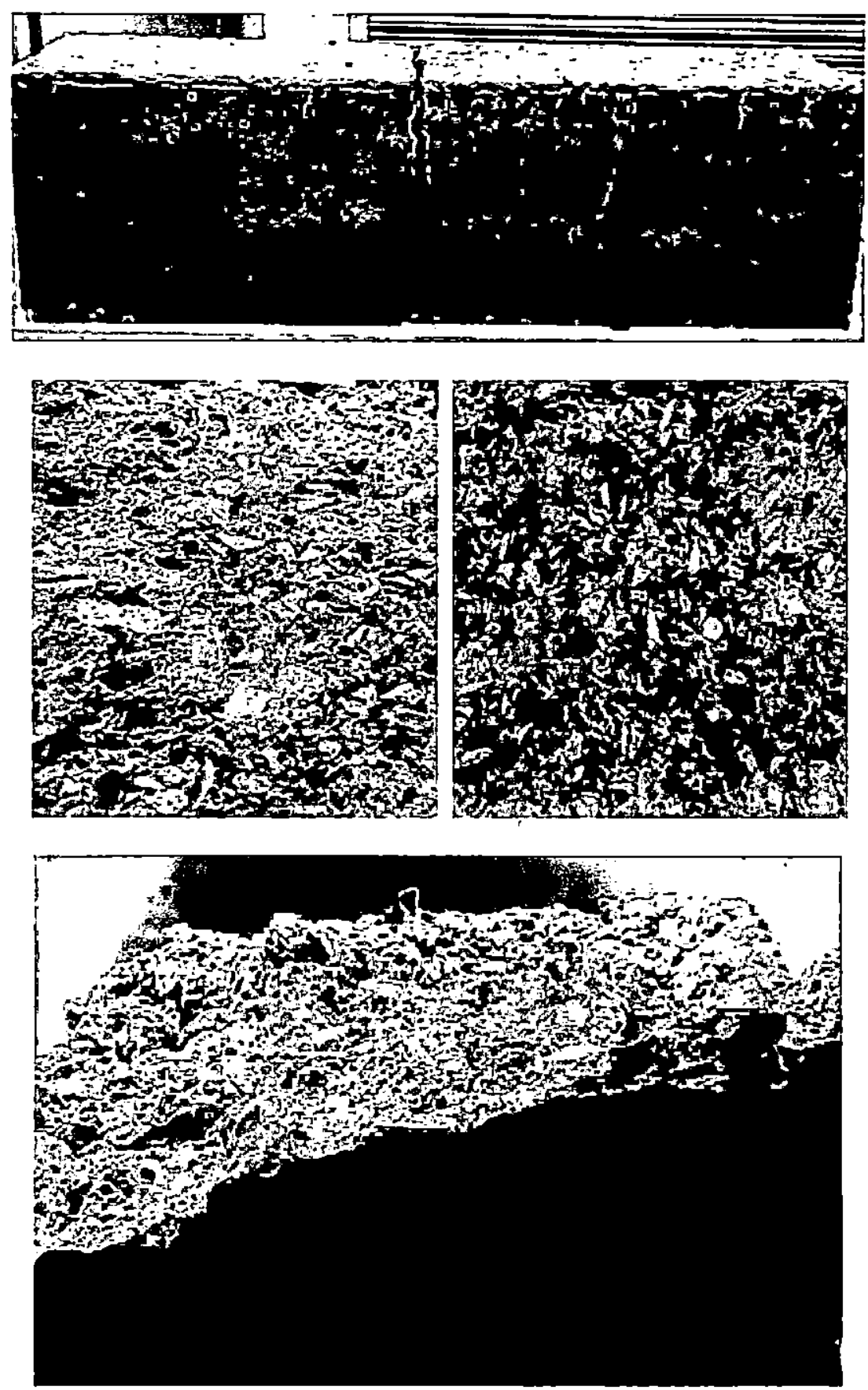

Fig. 7. Failure of beam of mix M1.5 under flexural load 


\title{
Properties of Hybrid Fiber-Reinforced Self- Consolidating Concrete
}

Sahar Y. Ghanem, Ph.D.

Biography: ACI member Sahar Ghanem is an Assistant Professor of construction management at Morehead State University at Morehead Kentucky. She received her PhD from University of Kentucky, Lexington, KY, in 2015. Her research interest is fiber reinforced composites, concrete, and masonry.

\begin{abstract}
This study is investigating the properties of self-consolidating concrete (SCC) containing synthetic polymer fibers. The influence of hybrid synthetic fiber reinforcement on concrete properties is reported. A total of six mixtures on which five of them are reinforced with fiber content ratio of $1 \%$ using several percent of macro and micro fibers. The concrete mixtures' density, filling ability, passing ability, segregation and compressive strength are determined. The test results showed that all mixtures with fiber have lower density, slump and J-Ring flow than unreinforced concrete. The less the macrofiber percent in the mixture, the higher the slump flow. all mixtures are classified as resistant for static segregation resistance. SCC compressive strength decreased drastically with adding fibers linearly. homopolymer polypropylene fibers in a collated fibrillated form will give smaller flow slump, smaller compressive strength, but larger penetration depth than mixtures with homopolymer polypropylene monofilament fibers.
\end{abstract}

Keywords: self-consolidating concrete; fiber reinforced concrete; synthetic fiber; micro fiber; macro fiber; hybrid fiber reinforcement. 


\section{Introduction}

Self-consolidating concrete (SCC) is flowable, nonsegregating concrete that can spread without mechanical consolidation (ACI Committee 237, 2007) - It was developed by Okamura (Okamura, et al., 1995) to overcome limited labor availability by flowing under its own weight and without any vibrating equipment.

Fibers are used to improve the properties of concrete, and various types of fibers are used for this purpose: steel fiber, glass fiber, natural fiber and synthetic fiber (Yin, et al., 2015). Since none of these fiber-reinforced concrete has the perfect mechanical properties, fibers with different materials or sizes are used together of what is called fiber hybridization.

Hybrid fiber composites was first used by Walton and Majumdar (Walton, et al., 1975), they concluded that that it is possible to produce satisfactory composites by mixing organic and inorganic fibers.

There are different bases to create a fibers hybrid based on: the fiber constitutive response, where the main variable is the fiber stiffness; fiber function where one fiber type is used to improve concrete fresh properties and the other type is used to improve the mechanical properties; and fiber dimensions where one type of fiber is smaller than the other (Banthia, et al., 2004; Bentur, et al., 1990; Lawler, et al.; Shah , 1991).

Using fiber with different dimensions was found to improve concrete properties. The smaller fibers (micro fiber) increase the strength by arresting the cracks at an early stage, while larger fibers (macro fibers) increase the post-cracking toughness (Lawler, et al.).

Fiber-reinforced self-consolidating concrete (FR-SCC) is highly flowable concrete in the fresh state with advanced performance in the hardened state. FR-SCC performance is measured 
using the same standard tests and employs the same adequate target values as for plain SCC (Ferrara, 2017).

Many researchers studied FR-SCC, with the majority focus on the steel fiber-SCC (Grunewald , et al., 2001; Corinaldesi , et al., 2004; Khayat, et al., 2014), and lately the focus shifted to different types of hybrid fiber SCC (Sahhmaran, et al., 2007; Nehdi , et al., 2004).

The purpose of this study is to investigate the properties of self-consolidating concrete containing synthetic polymer fibers. The influence of hybrid synthetic fiber reinforcement on concrete properties is reported. The hybrid combinations are based on the fiber dimensions and manufacturing method.

\section{Research Significance}

Hybrid fiber reinforced concrete properties has been studied deeply. Also, SCC incorporating steel fibers has been significantly studied. However, limited study has been conducted on the use of hybrid synthetic fibers in Self-consolidating concrete (SCC). The main purpose of this study is to examine the effect of hybrid synthetic fiber on the properties of Self-consolidating concrete (SCC). The research outcomes will help understand the behavior of hybrid fiber reinforced SCC.

\section{Experimental investigation}

\section{Materials}

Concrete has been produced using certain proportions of fine aggregate, coarse aggregate, cement, water, Superplasticizer, and Silica Fume. Then fibers are added with varied proportions. 
General purpose Portland cement Type I, Standard silica fume, Premium High Range Superplasticizer (HRWR), and coarse aggregate with a maximum size of $10 \mathrm{~mm}(0.39 \mathrm{in}$.) are used. Mixture proportions of the base matrix are given in Table 1.

Three types of synthetic fibers are used to reinforce concrete: macro fiber FORTAFERRO, micro fiber ECONO-NET, and micro fiber ECONO-MONO. Table 2 presents the fiber's mechanical properties; these data were obtained from the manufacturer website (FORTA Corporation).

Abbreviations $\mathrm{F}, \mathrm{N}$ and $\mathrm{M}$ will be used for fibers FORTA-FERRO, ECONO-NET, and ECONO-MONO respectively throughout the study. Figure 1 shows all fibers used in the study:

From Table 2 it can be seen that $\mathrm{N}$ fiber and $\mathrm{M}$ fiber are similar on all mechanical properties and length except the manufacturing method. $\mathrm{N}$ fiber is homopolymer polypropylene in a collated fibrillated form, while $\mathrm{M}$ fiber is a homopolymer polypropylene monofilament. (FORTA Corporation)

\section{Mixtures}

Six mixtures are designed: the first mixture (M0) is unreinforced concrete with zero fiber content ratio $\left(V_{f}\right)$, where $V_{f}$. represent the ratio between the fiber volume and concrete volume. The other five mixtures (M1 to M5) have the same total $V_{f}$ on all of them and that is equal to $1 \%$. The difference between mixtures is the percent of each type of the fibers F, N and M. Table 3 shows the mixes designed for this study.

Materials are mixed using a mixer. For mixtures with fibers, fibers are added at the end after all other materials are mixed. It was noticed that due to fiber small density, the fibers will stick to the mixer's walls. 


\section{Test Methods}

After mixing concrete, fresh concrete tests are performed immediately, and all specimens for hard concrete tests are placed in a water tank for 28 days before testing.

Several fresh concrete tests are performed. Density of SCC is calculated based on ASTM C138 (ASTM, 2017), this test is the standard test to determine the density of freshly mixed concrete. The filling ability was measured with respect to slump flow and is determinate based on ASTM C1611 (ASTM, 2014), where sample of freshly mixed concrete is placed in a mold in the inverted position without tamping, then the mold is raised. Slump flow is the average of two diameters measured of the spread concrete.

Passing ability is the ability of self-consolidating concrete to flow under its own weight and fill completely all spaces between reinforcement. This ability is tested using J-Ring test detailed in ASTM C1621 (ASTM, 2017). The procedure is similar to slump flow test but with adding special apparatus to behave as a rebar.

The last test performed on fresh concrete is penetration test, a test performed to the rapid assessment of static segregation resistance of concrete. Static segregation resistance is the resistance of concrete mixture to segregation of the mortar component from the coarse aggregate while the concrete is at rest and before initial setting (ASTM, 2017). Penetration test is performed based on ASTM C1712 (ASTM, 2017) where a sample of fresh SCC is placed in an inverted slump mold without tamping, then a hollow cylinder is lowered onto the surface of the concrete and released to freely penetrate into the fresh concrete. The penetration depth is used to assess the static segregation.

The hard-concrete test performed is this study is compressive strength of cylindrical concrete specimens in accordance to ASTM C39 (ASTM, 2017). The test consists of applying a 
compressive axial load to molded cylinders until failure occurs. The compressive strength of the specimen is calculated by dividing the maximum load attained during the test by the crosssectional area of the specimen (ASTM, 2017).

\section{Results and Discussions}

\section{Density}

The experimental values for density are shown in Table 4 and Figure 2 . All mixtures with fiber have lower density than unreinforced concrete M0. This is expected because fibers have lower density than concrete.

In fiber reinforced mixtures, the lowest density recorded is equal to $2433 \mathrm{~kg} / \mathrm{m}^{3}(151.8$ $\left.\mathrm{Ib} / \mathrm{ft}^{3}\right)$ for mixture M3, while highest is for mixture M1 and equal to $2651 \mathrm{~kg} / \mathrm{m}^{3}\left(165.4 \mathrm{Ib} / \mathrm{ft}^{3}\right)$.

\section{Filling ability}

The results for slump flow test are shown in Table 4 and Figure 3. All mixtures with fiber have lower slump flow compared to unreinforced concrete M0. Since in this study the quantity of HRWR intended to be the same for all mixes, it can be clearly seen that the value of the slump flow dropped significantly by adding fibers, and the level of flow of unreinforced mixture could not be achieved without adjusting the HRWR quantity.

In fiber reinforced mixtures, mixture M1 with macrofiber $(\mathrm{F})$ showed the lowest slump value, while mixture M5 showed the highest slump value. This mixture (M5) contains the $0.6 \%$ of microfibers, which gives the highest percent of microfiber of all mixtures. Therefore, the less the macrofiber percent in the mixture, the higher the slump flow. 
The effect of fiber manufacturing method is carried out by comparing mixtures M2 and M3. Slump flow for M2 which contains $0.5 \%$ of $\mathrm{N}$ fiber is less than $\mathrm{M} 3$ that contains $\mathrm{M}$ fibers. Therefore, homopolymer polypropylene fibers in a collated fibrillated form will give less flowable mixture than mixtures with homopolymer polypropylene monofilament fibers.

\section{Passing ability}

The results for J-Ring test are shown in Table 4 and Figure 4. All mixes with fiber have lower J-Ring flow compared to unreinforced concrete M0. In fiber reinforced mixtures, results for this test are similar to filling ability test where mixture M1 with macrofiber (F) showed the lowest J-Ring flow value, while mixture M5 showed the highest J-Ring flow value.

The effect of fiber manufacturing method is carried out by comparing mixtures M2 and M3. J-Ring flow for $\mathrm{M} 2$ which contains $0.5 \%$ of $\mathrm{N}$ fiber is equal to $\mathrm{M} 3$ that contains $\mathrm{M}$ fibers.

To identify the blocking assessment, the passing ability as the difference between the slump flow and J-Ring flow is calculated to the nearest $10 \mathrm{~mm}$ [1/2 in.] (ASTM, 2017). The results are reported in Table 4 and Figure 5.

Based on the results of the passing ability and the ASTM standards (ASTM, 2017), the identified blocking assessment is as the following: for M0 and M5 it is noticeable to extreme blocking, and for mixtures M1 to M4 it is visible blocking.

\section{Segregation Resistance}

The recorded penetration depths $(P d)$ measured in penetration test are recorded in Table 4 and Figure 6. Based on the results of the penetration test and the ASTM standards (ASTM, 2017) , all mixtures are considered as resistant for static segregation resistance. 
The effect of fiber manufacturing method is carried out by comparing mixtures $\mathrm{M} 2$ and M3. The penetration depth for M2 which contains $0.5 \%$ of $\mathrm{N}$ fiber is larger to $\mathrm{M} 3$ that contains M fibers.

\section{Compressive strength}

The only test performed on hardening concrete in this study is compressive strength of cylindrical concrete specimens test. Cylinders with dimensions of $150 \mathrm{~mm}$ (6 in.) by $300 \mathrm{~mm}$ (12 in.) are prepared and tested at 28 days. The results of the test are lists in Table 4 and Figure 7.

SCC compressive strength decreased drastically with adding fibers. Except for M2, with increasing the microfiber percent in the mixture, the compressive strength decreases linearly (Fig. 7). This is because the fibers replace some of the coarse and fine aggregates, which decreased the compressive strength of the concrete mixtures (Aydin, 2007).The lowest decrease percent is for mixture M1 that contains only macrofibes and that was $21.8 \%$. The highest decrease in the compressive strength is for mixture M5 with $0.8 \%$ microfibers, and it is calculated as $53.6 \%$.

Although both M2 and M3 mixtures have same percent of microfiber, M3 has a higher compressive strength. Therefore, homopolymer polypropylene fibers in a collated fibrillated form will give less compressive strength than mixtures with homopolymer polypropylene monofilament fibers.

The failure mode is different between unreinforced and fiber reinforced concrete. For unreinforced concrete, the cylinder failed suddenly after cracks formed diagonally and the specimen break into two pieces as shown in Figure 8- a. 
Failure for M1 mixture with only macrofiber is shown in Figure 8- b. A crack formed diagonally but the specimen stayed in contact, the force in the testing machine felled down after that. It can be seen that the fibers are crossed over the crack and prevented the crack to expand and separate the cylinder into two pieces.

M2 failed by forming columnar vertical cracks (Fig. 8-c), while M3 failed by forming cracks closer to cone shape (Fig. 8-d). Both cylinders did not break completely into pieces at failure.

M4 failed by forming columnar vertical cracks (Fig. 8-e). Although both M1 and M4 developed a diagonal crack at failure, it can be noticed that the crack in specimen of mixture M1 propagated and separated more than the crack in M4 specimen. The reason for that is the usage of microfibers resists the propagation of cracks (Lawler, et al.).

M5 failed by forming cracks closer to cone shape (Fig. 8-f). It can be seen as the macrofiber percent in the mixture dropped under certain percent and the microfiber percent increased above certain percent, the cracks begin to propagate more again. An intensive experimental study is required to specify the best macrofiber to microfiber percent in the mixture to resist cracks.

\section{Summary and conclusions}

This study is investigating the properties of self-consolidating concrete (SCC) containing synthetic polymer fibers. The influence of hybrid synthetic fiber reinforcement on concrete properties is reported. The hybrid combinations are based on the fiber dimensions and manufacturing method. 
A total of six mixtures on which five of them are reinforced with fiber content ratio of $1 \%$ using several percent of macro and micro fibers. The concrete mixtures' density, filling ability, passing ability, segregation and compressive strength are determined Based on the test results of this study on fiber reinforced self-consolidating concrete (SCC), the following conclusions can be made:

- All mixtures with fiber have lower density than unreinforced concrete. This is because fibers have lower density than concrete.

- All mixtures with fiber have lower slump and J-Ring flow compared to unreinforced concrete

- The less the macrofiber percent in the mixture, the higher the slump flow.

- all mixtures are classified as resistant for static segregation resistance.

- SCC compressive strength decreased drastically with adding fibers. Except for M2, with increasing the microfiber percent in the mixture, the compressive strength decreases linearly

- The fiber manufacturing method affected some of the SCC properties: homopolymer polypropylene fibers in a collated fibrillated form will give smaller flow slump, smaller compressive strength, but larger penetration depth than mixtures with homopolymer polypropylene monofilament fibers.

- An intensive experimental study is required to specify the best macrofiber to microfiber percent in the mixture to resist cracks. 


\section{Acknowledgments}

Financial support for the project was made available by the Research and Creative

Productions Committee, Morehead State University.

The author is also grateful to Forta Concrete Fiber for supplying fibers that were used in the experiment. The author would like to acknowledge the assistance of Jonathan Bowling for setting up the experiment materials.

\section{List of Notations}

$V_{f}$ : fiber content ratio and represent the ratio between the fiber volume and concrete volume.

$P d$ : The recorded penetration depths measured in penetration test.

\section{References}

[Online]. - Forta Concrete Fiber. - http://www.forta-ferro.com.

Khayat K., Kassimi F. and Ghoddo P. Mixture Design and Testing of Fiber-Reinforced Self-Consolidating Concrete [Journal] // ACI Materials Journal. - 2014. - 2 : Vol. 111. - pp. 143152.

ACI Committee 237 ACI 237R-07: Self-Consolidating Concrete [Report]. - Farmington Hills, MI : American Concrete Institute, 2007.

ASTM C138/C138M-17a : Standard Test Method for Density (Unit Weight), Yield, and Air Content (Gravimetric) of Concrete [Report]. - West Conshohocken, PA : ASTM International, 2017. - https://doi.org/10.1520/C0138 C0138M-17A.

ASTM C1611/C1611M-14 Standard Test Method for Slump Flow of Self-Consolidating Concrete [Report]. - West Conshohocken, PA : ASTM International, 2014. https://doi.org/10.1520/C1611_C1611M-14.

ASTM C1621/C1621M-17 Standard Test Method for Passing Ability of Self-Consolidating Concrete by J-Ring [Report]. - West Conshohocken, PA : ASTM International, 2017. https://doi.org/10.1520/C1621_C1621M-17.

ASTM C1712-17 Standard Test Method for Rapid Assessment of Static Segregation Resistance of Self-Consolidating Concrete Using Penetration Test [Report]. - West Conshohocken, PA : ASTM International, 2017. - https://doi.org/10.1520/C1712-17. 
ASTM C39/C39M-17 Standard Test Method for Compressive Strength of Cylindrical Concrete Specimens [Report]. - West Conshohocken, PA : ASTM International, 2017. https://doi.org/10.1520/C0039_C0039M-17.

Banthia N. and Gupta R. Hybrid fiber reinforced concrete (HyFRC): fiber synergy in high strength matrices [Journal] // Materials and Structures. - 2004. - 10 : Vol. 37. - pp. 707-716.

Bentur A. and Mindess S. Fiber Reinforced Cementitious Composites [Book]. - London, UK : Elsevier Applied Science, 1990.

Corinaldesi V. and Moriconi G. Durable fiber reinforced self-compacting concrete [Journal] // Cement and Concrete Research. - 2004. - 2 : Vol. 34. - pp. 249-254.

Ferrara Liberato Fibre-reinforced cementitious composites with adapted rheology: From stateof-the-art knowledge towards new boundaries for structural concrete applications [Article] // ACI Special Publication. - 2017. - Vol. 310. - pp. 91-102.

Grunewald S. and Walraven JC. Parameter study on the influence of steel fibers and coarse aggregate content on the fresh properties of self-compacting concrete [Journal] // Cement and Concrete Research. - 2001. - 12 : Vol. 31. - pp. 1793-1798.

Lawler J. S., Zampini D. and Shah S. P. Microfiber and Macrofiber Hybrid Fiber-Reinforced Concrete [Journal] // Journal of Materials in Civil Engineering, ASCE. - 5 : Vol. 17. - pp. 595604. doi: 10.1061/(ASCE)0899-1561(2005)17:5(595).

Nehdi M. and Ladanchuk J. Fiber Synergy in Fiber-Reinforced Self-Consolidating Concrete [Journal] // ACI Materials Journal. - 2004. - 6 : Vol. 101. - pp. 508-517.

Okamura H. and Ozawa K. Mix-Design for Self-Compacting Concrete," Concrete Library of JSCE [Journal] // Concrete Library of JSCE. - 1995. - Vol. 25. - pp. 107-120.

Sahhmaran M. and Yaman IO. Hybrid fiber reinforced self-compacting concrete with a highvolume coarse fly ash [Journal] // Construction and Building Materials. - 2007. - 1 : Vol. 21. pp. 150-156.

Shah SP Do fibers increase the tensile strength of cement-based matrixes? [Journal] // ACI Materials Journal. - 1991. - 6 : Vol. 88. - pp. 595-602.

Walton P.L. and Majumdar A.J. Cement-based composites with mixtures of different types of fibres [Journal] // Composites. - 1975. - 5 : Vol. 6. - pp. 209-216.

Yin S [et al.] Use of macro plastic fibres in concrete: A review [Journal] // Construction and Building Materials. - 2015. - Vol. 93. - pp. 180-188. DOI: 10.1016/j.conbuildmat.2015.05.105. 


\section{Tables}

Table 1- Mixture Proportions of the base mixture

\begin{tabular}{|c|c|c|c|c|c|}
\hline Cement & Fine aggregate & $\begin{array}{c}\text { Coarse } \\
\text { Aggregate }\end{array}$ & Water & Silica Fume & $\begin{array}{c}\text { Superplasticize } \\
\mathrm{r}\end{array}$ \\
\hline $\mathrm{kg} / \mathrm{m}^{3}\left(\mathrm{lb} / \mathrm{ft}^{3}\right)$ & $\mathrm{kg} / \mathrm{m}^{3}\left(\mathrm{lb} / \mathrm{ft}^{3}\right)$ & $\mathrm{kg} / \mathrm{m}^{3}\left(\mathrm{lb} / \mathrm{ft}^{3}\right)$ & $\mathrm{kg} / \mathrm{m}^{3}\left(\mathrm{lb} / \mathrm{ft}^{3}\right)$ & $\mathrm{kg} / \mathrm{m}^{3}\left(\mathrm{lb} / \mathrm{ft}^{3}\right)$ & $\mathrm{L} / \mathrm{m}^{3}\left(\mathrm{~L} / \mathrm{ft}^{3}\right)$ \\
\hline 488 & 867 & 816 & 200 & 42 & 5 \\
$(30.5)$ & $(54)$ & $(51)$ & $(12.5)$ & $(2.6)$ & $(0.14)$ \\
\hline
\end{tabular}

Table 2- Mechanical properties of fibers (FORTA Corporation)

\begin{tabular}{|c|c|c|c|}
\hline Property & FORTA -FERRO (F) & ECONO-NET (N) & ECONO-MONO (M) \\
\hline $\begin{array}{c}\text { Tensile Strength, MPa } \\
\text { (ksi) }\end{array}$ & $570-660(83-96)$ & $570-660(83-96)$ & $570-660(83-96)$ \\
\hline Specific Gravity & 0.91 & 0.91 & 0.91 \\
\hline $\begin{array}{c}\text { Fiber Length, mm } \\
\text { (in.) }\end{array}$ & $54(2.25)$ & $19(0.75)$ & $19(0.75)$ \\
\hline Density, $\mathbf{~ k g / \mathbf { m } ^ { 3 }} \mathbf{( \mathbf { b } / \mathbf { y d } ^ { \mathbf { 3 } } )}$ & $910(1,534)$ & $910(1,534)$ & $910(1,534)$ \\
\hline
\end{tabular}

Table -3- Volume Fraction of Fibers used in Various Mixes

\begin{tabular}{|c|c|c|c|c|}
\hline Mix & $\begin{array}{l}\text { Volume of } \\
\text { various fiber } \\
\text { types (\%) }\end{array}$ & & & \\
\hline & $\mathbf{F}$ & $\mathbf{N}$ & $\mathbf{M}$ & Total $V_{f}$ \\
\hline M0 & 0 & 0 & 0 & 0 \\
\hline M1 & 1 & 0 & 0 & 1 \\
\hline M2 & 0.5 & 0.5 & 0 & 1 \\
\hline M3 & 0.5 & 0 & 0.5 & 1 \\
\hline M4 & 0.4 & 0.3 & 0.3 & 1 \\
\hline M5 & 0.2 & 0.4 & 0.4 & 1 \\
\hline
\end{tabular}


Table -4- Test results and on hybrid fiber-reinforced self- consolidating concrete

\begin{tabular}{|c|c|c|c|c|c|c|c|c|c|}
\hline Mix & $\begin{array}{c}\text { Fiber } \\
\%\end{array}$ & & & Density & $\begin{array}{c}\text { Slump } \\
\text { flow }\end{array}$ & $\begin{array}{c}\text { J-Ring } \\
\text { flow }\end{array}$ & $\begin{array}{c}\text { The } \\
\text { passing } \\
\text { ability }\end{array}$ & $\begin{array}{c}\text { penetr } \\
\text { ation } \\
\text { depth } \\
(P d)\end{array}$ & 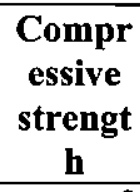 \\
\hline & $\mathbf{F}$ & $\mathbf{N}$ & $\mathbf{M}$ & $\left(\mathrm{kg} / \mathrm{m}^{3}\right)$ & $(m m)^{*}$ & $(m m)^{\star}$ & $(m m)^{*}$ & $(m m)^{*}$ & $(M P a)^{*}$ \\
\hline M0 & 0 & 0 & 0 & 2674 & 690 & 570 & 120 & 4 & 45.64 \\
\hline M1 & 1 & 0 & 0 & 2651 & 360 & 340 & 20 & 2 & 35.69 \\
\hline M2 & 0.5 & 0.5 & 0 & 2584 & 390 & 380 & 10 & 4 & 28.79 \\
\hline M3 & 0.5 & 0 & 0.5 & 2433 & 400 & 380 & 20 & 1 & 29.38 \\
\hline M4 & 0.4 & 0.3 & 0.3 & 2441 & 380 & 360 & 20 & 1 & 24.79 \\
\hline M5 & 0.2 & 0.4 & 0.4 & 2534 & 430 & 390 & 70 & 0 & 21.2 \\
\hline
\end{tabular}

${ }^{*} 1 \mathrm{~kg} / \mathrm{m}^{3}=0.0624 \mathrm{Ib} / \mathrm{ft}^{3} ; 1 \mathrm{~mm}=0.039 \mathrm{in} . ; 1 \mathrm{MPa}=0.145 \mathrm{ksi}$ 
Figures

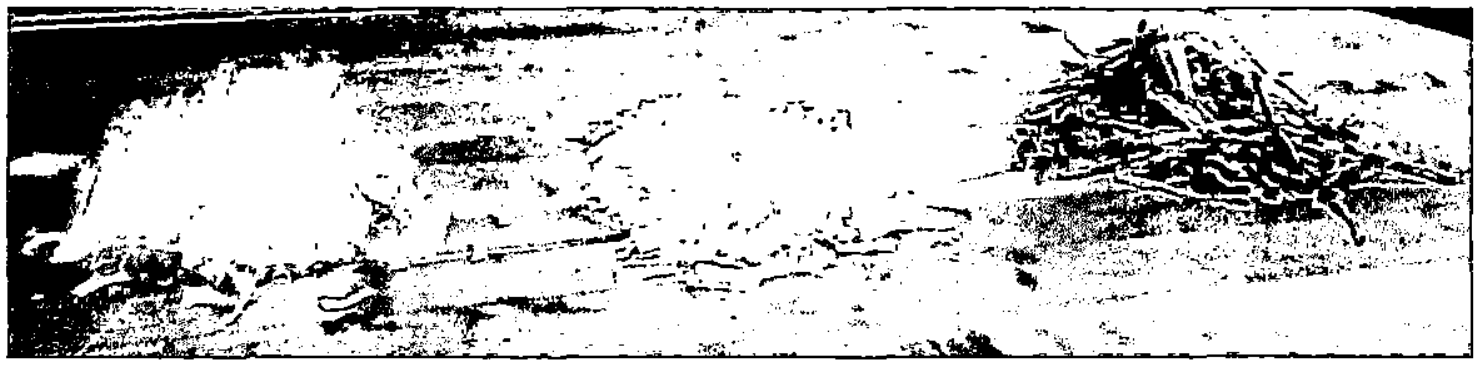

Fig.1-Fibers used in the study starting from the right: FORTA-FERRO (F), ECONO $\operatorname{NET}(N)$, and ECONO-MONO (M).

\section{Density vs Mixture}

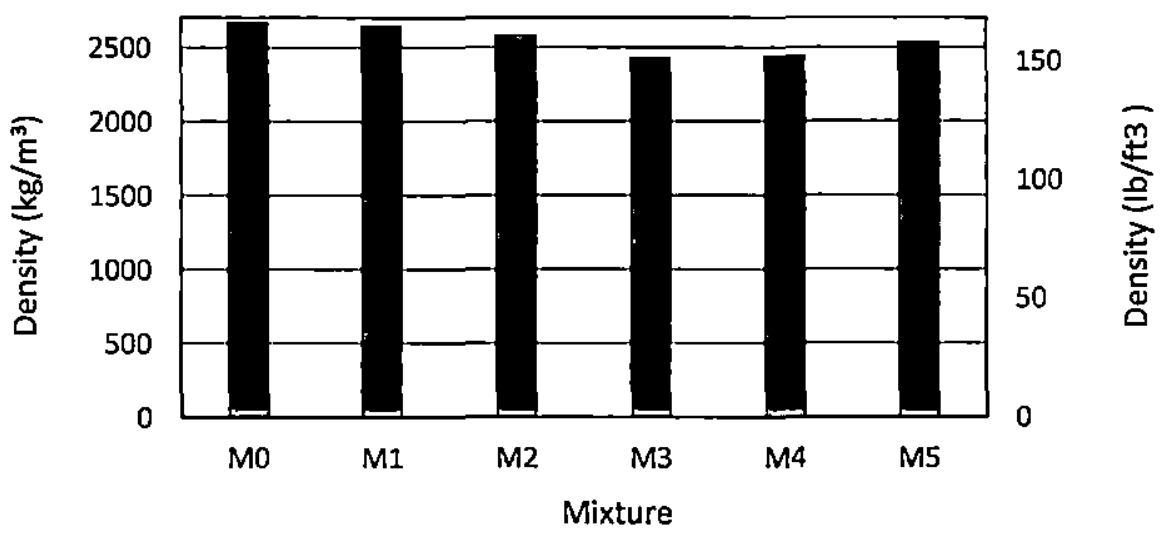

Fig. 2-Density for all mixtures 


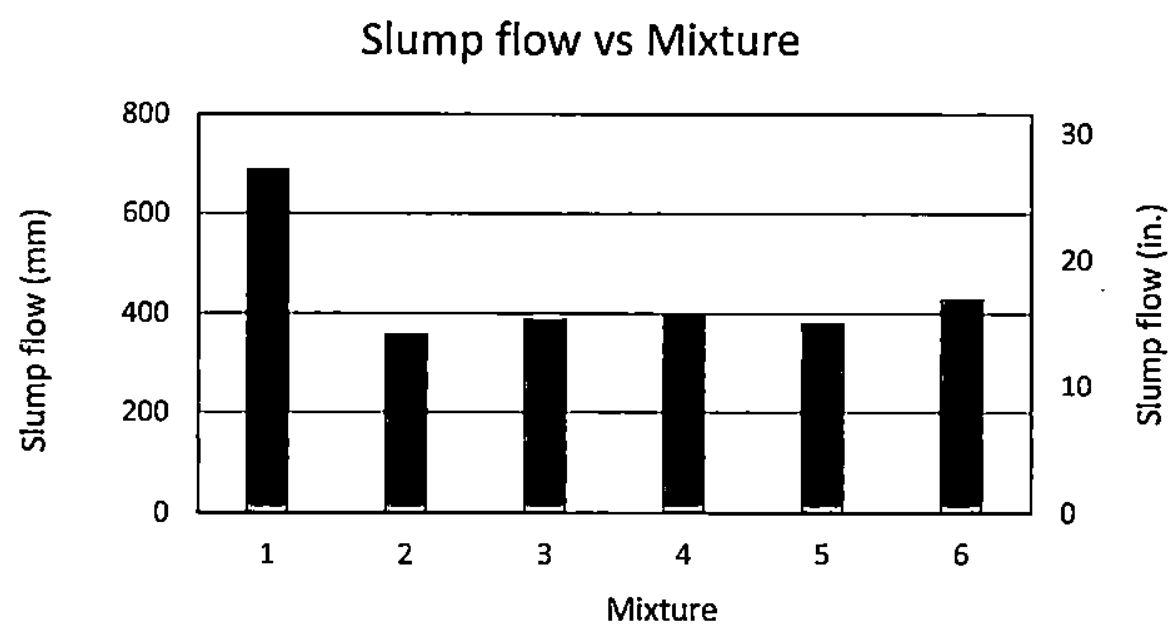

Fig. 3-Slump flow for all mixtures

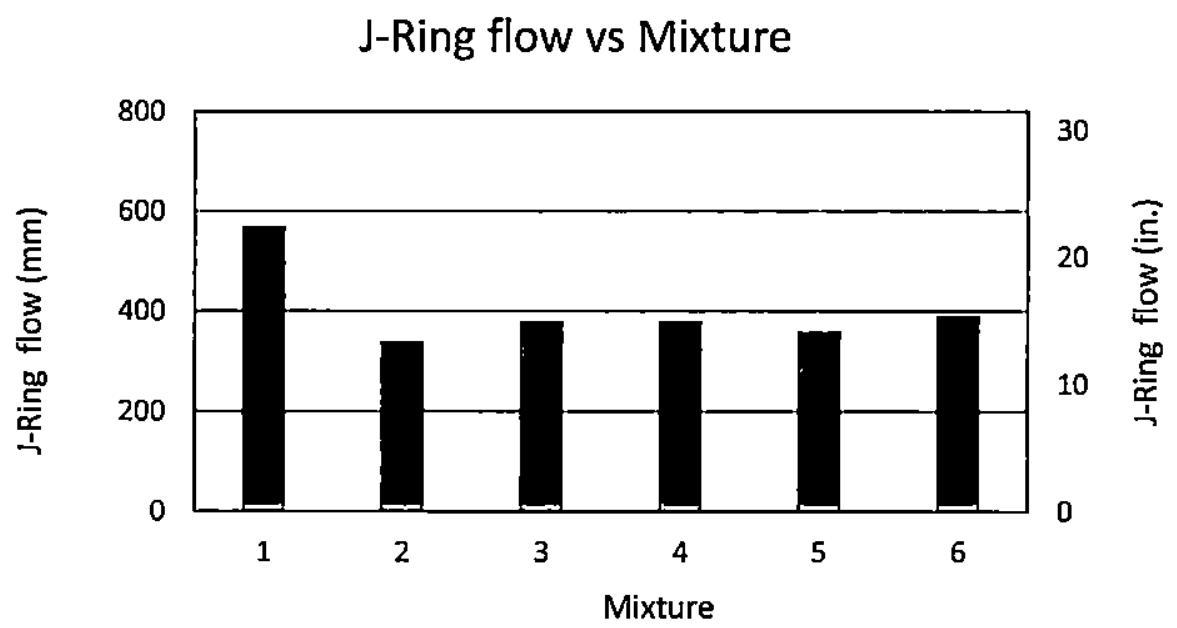

Fig. 4-J-Ring flow for all mixtures 


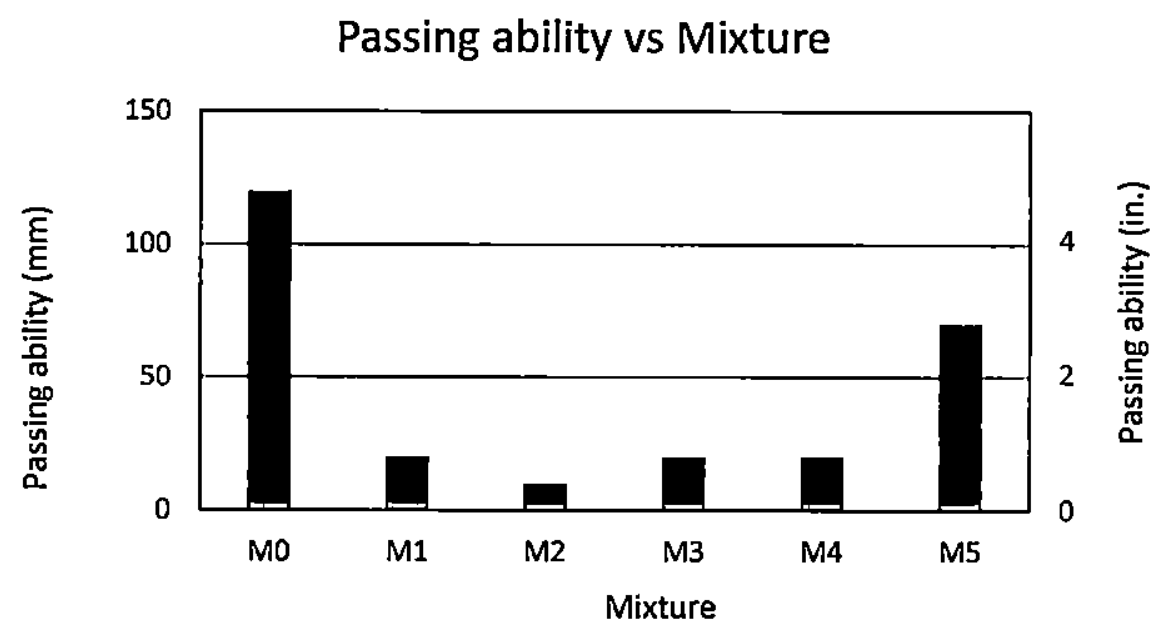

Fig. 5-Passing ability for all mixtures

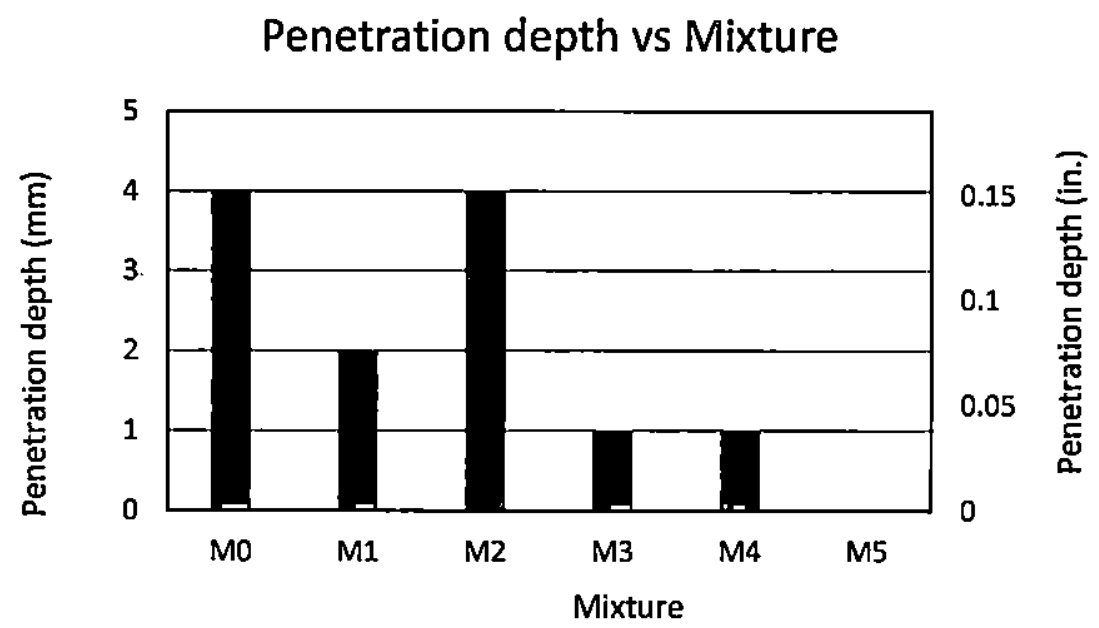

Fig. 6-Penetration depth for all mixtures 
Compressive strength vs Mixture

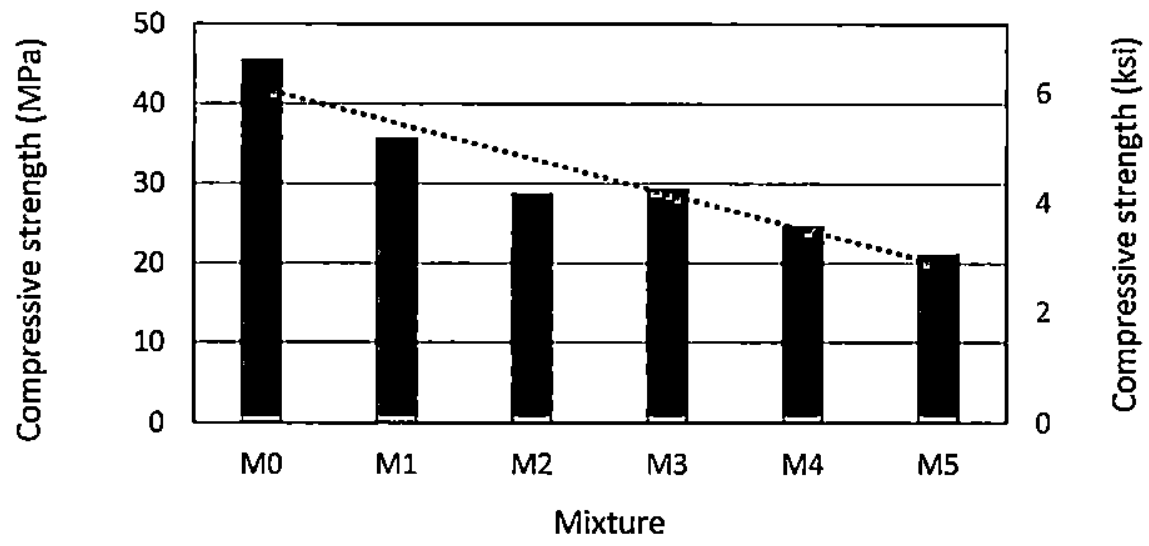

Fig. 7-Compressive strength for all mixtures 


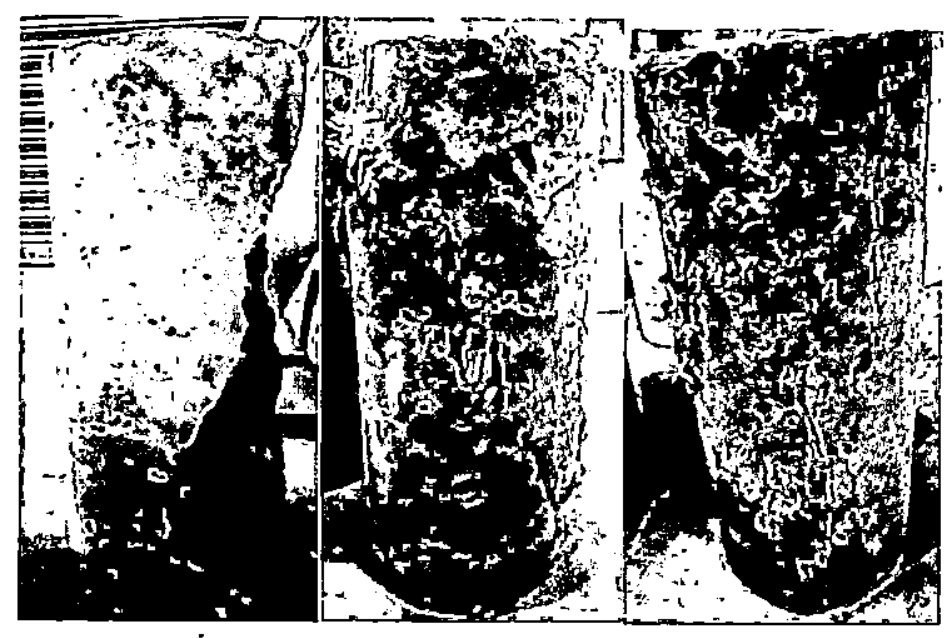

(a)

(b)

(c)

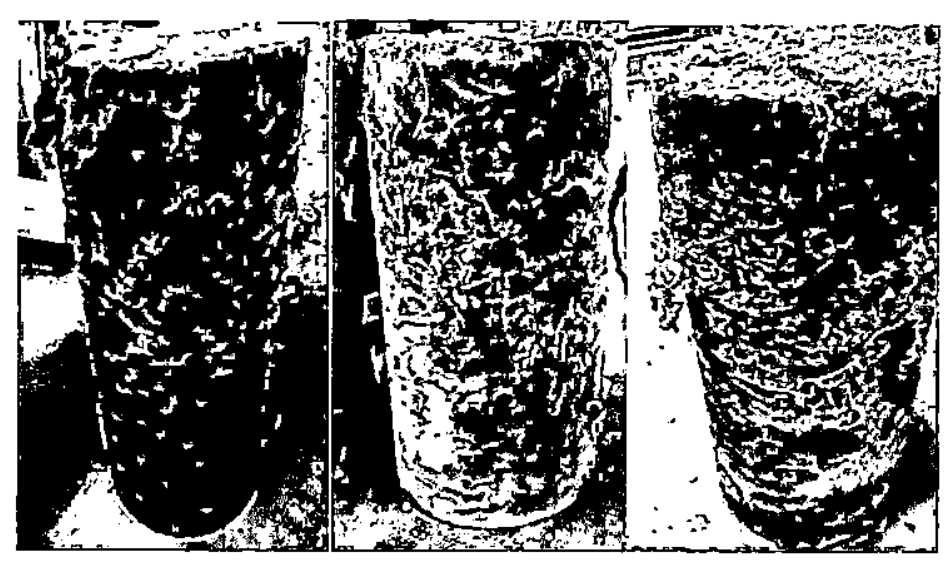

(d)

(e)

(f)

Fig. 8- Failure of cylinder under concentric compressive load for mixture: a) $M 0, b) M 1$, c) $M 2$, d) $M 3$, e) $M 4, f) M 5$ 


\section{List of Tables}

Table 1- Mixture Proportions of the base mixture

Table 2-Mechanical properties of fibers (FORTA Corporation)

Table 3-Volume Fraction of Fibers used in Various Mixes

Table $-4-$ Test results and on hybrid fiber-reinforced self- consolidating concrete

\section{List of Figures}

Fig.1 - Fibers used in the study starting from the right: FORTA -FERRO (F), ECONO NET (N), and ECONO-MONO (M).

Fig. 2-Density for all mixtures.

Fig. 3 - Slump flow for all mixtures

Fig. 4 - J-Ring flow for all mixtures

Fig. 5- Passing ability for all mixtures

Fig. 6 - Penetration depth for all mixtures

Fig. 7 - Compressive strength for all mixtures

Fig. 8 - Failure of cylinder under concentric compressive load for mixture: a) M0, b) M1, c) M2, d) M3, e) M4, f) M5 